\title{
Studies of Dihydropyridines by X-Ray Diffraction and Solid State ${ }^{13}$ C NMR
}

\author{
Martha S. Morales-Ríos ${ }^{\mathrm{a}}$, Antonio Martínez-Richa ${ }^{\mathrm{b}}$, Zurisaddai Hernández-Gallegos ${ }^{\mathrm{a}}$, \\ Angelina Hernández-Barragán ${ }^{\mathrm{a}}$, Ricardo Vera-Graziano ${ }^{\mathrm{c}}$, and Pedro Joseph-Nathan ${ }^{\mathrm{a}}$ \\ ${ }^{a}$ Departamento de Química and Sección Externa de Farmacología, Centro de Investigación y \\ de Estudios Avanzados del Instituto Politécnico Nacional, Apartado 14-740, México D. F., \\ 07000 México \\ b Facultad de Química, Universidad de Guanajuato, Noria alta s/n, Guanajuato, Gto 36050, México \\ c Instituto de Investigaciones en Materiales, UNAM, Apartado 70-360, Coyoacán, México D. F., \\ 04510 México
}

Reprint requests to Prof. Dr. M. S. Morales-Ríos. Fax: 525557477137.

E-mail: smorales@ cinvestav.mx

Z. Naturforsch. 2007, 62b, 549-555; received October 10, 2006

Fourteen dimethyl 4-aryl-2,6-dimethyl-1,4-dihydropyridine-3,5-dicarboxylates (DHPs) were evaluated by means of single crystal X-ray diffraction in order to investigate the effects of the structure in the crystals on the solid state ${ }^{13} \mathrm{C}$ NMR chemical shifts. These include the analysis of three DHPs containing two molecules per asymmetric unit. The chiral rotamer unit generated by the s-cis/s-trans orientation of the carbonyl groups, as well as by rotation of the 4-phenyl ring out of the bisecting plane containing the $\mathrm{N} 1, \mathrm{C} 4, \mathrm{C} 7$ atoms, resulted in a significant magnetic non-equivalence for the $\mathrm{C} 2-\mathrm{CH}_{3} / \mathrm{C} 6-\mathrm{CH}_{3}$ and the $\mathrm{COOCH}_{3}$ pairs of signals. The solid state ${ }^{13} \mathrm{C}$ NMR data reveal that the substitution pattern of the phenyl ring has a marked effect on the extent to which the signals of the carbonyl carbon atoms and those of C-2/C-6 peaks are split.

Key words: ${ }^{13}$ C CP-MAS NMR, 1,4-Dihydropyridines, Chiral Rotamers, Crystal Structures

\section{Introduction}

1,4-Dihydropyridine derivatives (DHPs) are L-type calcium channel blockers. The nifedipine prototype and other DHPs have been approved for clinical use in the management of a wide variety of cardiovascular diseases like hypertension, exertional and vasospastic angina, certain types of cardiac arrhythmias, and others $[1,2]$. DHPs act directly on the L-type voltage-gated calcium channel $\left(\mathrm{Ca}_{\mathrm{v}} 1\right.$ subfamily, in accord with the new nomenclature) [3], blocking the transmembrane flux of calcium ions from the extracellular medium to the interior of cells. The DHPs bind specifically to the $\alpha 1$ subunit of the channel and there are evidences that suggest they act allosterically to stabilize the closed channel mode, rather than by occluding the pore $[4,5]$.

It is well known that most drugs (around 90\%) are formulated as solids. The ability to effectively deliver solid pharmaceuticals strongly depends upon the form of the drug in the solid state. In that regard, knowledge of the actual arrangement adopted by the

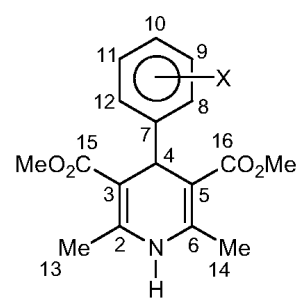

$$
\begin{array}{lr}
\mathbf{1} X=\mathrm{H} & \mathbf{8} \mathrm{X}=9,11-\mathrm{F} \\
\mathbf{2} X=8-\mathrm{Me} & \mathbf{9} \mathrm{X}=8-\mathrm{Cl} \\
\mathbf{3} \mathrm{X}=9-\mathrm{Me} & \mathbf{1 0} \mathrm{X}=9-\mathrm{Cl} \\
\mathbf{4} \mathrm{X}=10-\mathrm{Me} & \mathbf{1 1} \mathrm{X}=10-\mathrm{Cl} \\
\mathbf{5} \mathrm{X}=8-\mathrm{F} & \mathbf{1 2} \mathrm{X}=8-\mathrm{NO}_{2} \\
\mathbf{6} \mathrm{X}=9-\mathrm{F} & \mathbf{1 3} \mathrm{X}=9-\mathrm{NO}_{2} \\
\mathbf{7} \mathrm{X}=10-\mathrm{F} & \mathbf{1 4} \mathrm{X}=10-\mathrm{NO}_{2}
\end{array}
$$

Fig. 1. Molecular structure of dihydropyridines.

molecule in the crystal lattice is important to establish structure-property relationships for drug bioavailability [6]. Over the last few decades methodologies for obtaining atomic level structures of drugs in the solid state involve a combination of several techniques, such as X-ray diffraction and solid state ${ }^{13} \mathrm{C}$ NMR spec- 


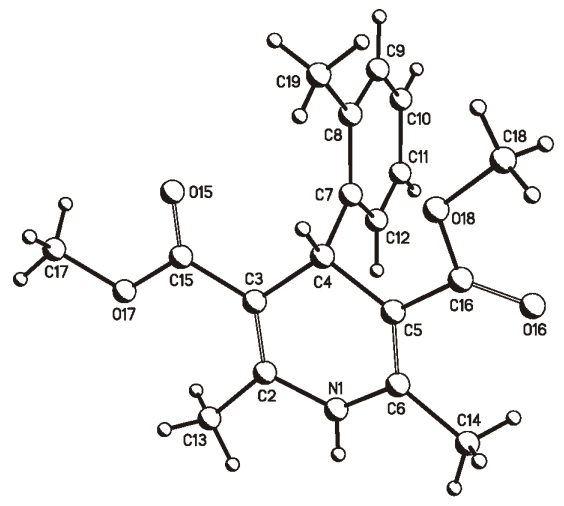

molecule 1

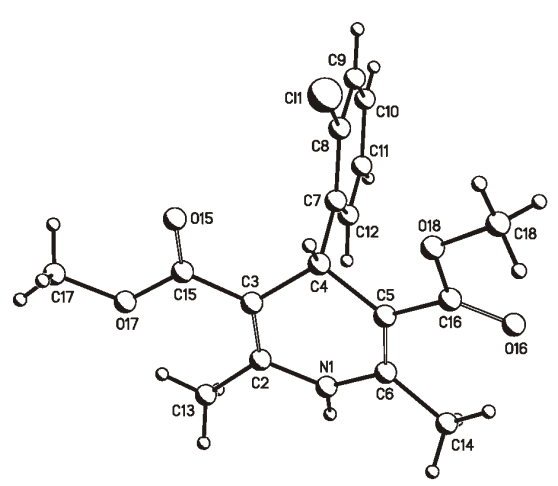

molecule 1

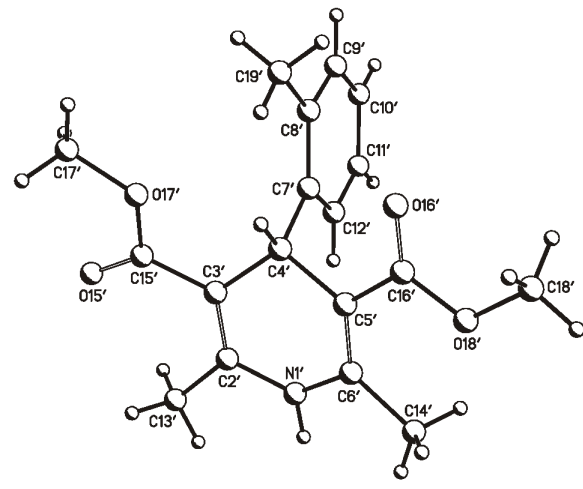

molecule 2

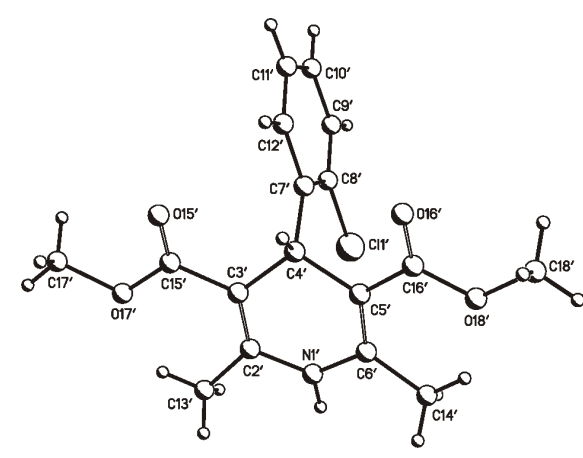

molecule 2
Fig. 2. Structure of the molecules in the crystals of 2.
Fig. 3. Structures of the molecules in the crystals of 9, generated from published atomic coordinates [8]. troscopy. Many studies have demonstrated that X-ray diffraction analysis provides very useful information about the specific conformation of crystalline dihydropyridines [6-10], however only few data on solid state ${ }^{13} \mathrm{C}$ NMR for these compounds have hitherto been reported [11-13]. An interesting facet of such experiments on solids is that dynamic conformational averaging is often absent. In the solid state, restricted bond rotation imposed by the environment can lead to the observation of a specific conformation. In some cases, the conformation observed in the solid state induces a non-equivalent chemical environment, which in turn provokes the presence of additional ${ }^{13} \mathrm{C} N M R$ signals. In this work, we report a set of assigned solution and solid state ${ }^{13} \mathrm{C}$ NMR spectra for representative 2,6-dimethyl-3,5-dimethoxycarbonyl-4-(substituted-phenyl)-1,4-dihydropyridines 1 - 14 (Fig. 1) including data for prototypical nifedipine (12) [13]. The information obtained from both techniques can be used to understand the overall geometrical characteristics of the dihydropyridines and related molecules.

\section{Results and Discussion}

\section{$X$-Rray diffraction studies}

X-Ray crystal structures for DHPs 2, 5-8 and 10 were determined for the first time. Crystals suitable for $\mathrm{X}$-ray analysis were also obtained for 3, 4 and $\mathbf{1 1 -}$ 14. Two polymorphic forms (monoclinic prisms and orthorhombic prisms) of $\mathbf{1 1}$ were identified and characterized, one of which was previously unrecognized. $\mathrm{X}$-Ray data for $\mathbf{1}$ and $\mathbf{9}$ were taken from the literature $[7,8]$. In the case of $\mathbf{2}, \mathbf{9}$ and the orthorhombic polymorph 11, the presence of two molecules per asymmetric unit was observed (see Figs. 2-4). The crystal data and refinement details for new polymorphic forms are summarized in Table 1.

The frozen conformation observed in the crystal structure for the compounds studied (1-14, Table 2) reveals a preferred arrangement, with the dihydropyridine ring in a boat form [14] flattened at the N1 (stern) and puckered at the $\mathrm{C} 4$ (bow) atoms as evidenced by the distances of $\mathrm{N} 1$ and $\mathrm{C} 4$ to the main 
Table 1. X-Ray data collection and processing parameters for $\mathbf{2 , 5 - 8 , 1 0}$ and 11.

\begin{tabular}{|c|c|c|c|c|c|c|c|}
\hline Compound & 2 & 5 & 6 & 7 & 8 & 10 & 11 \\
\hline Formula & $\mathrm{C}_{17} \mathrm{H}_{21} \mathrm{O}_{4} \mathrm{~N}$ & $\mathrm{C}_{17} \mathrm{H}_{18} \mathrm{O}_{4} \mathrm{NF}$ & $\mathrm{C}_{17} \mathrm{H}_{18} \mathrm{O}_{4} \mathrm{NF}$ & $\mathrm{C}_{17} \mathrm{H}_{18} \mathrm{O}_{4} \mathrm{NF}$ & $\mathrm{C}_{17} \mathrm{H}_{17} \mathrm{O}_{4} \mathrm{NF}_{2}$ & $\mathrm{C}_{17} \mathrm{H}_{18} \mathrm{O}_{4} \mathrm{NCl}$ & $\mathrm{C}_{17} \mathrm{H}_{18} \mathrm{O}_{4} \mathrm{NCl}$ \\
\hline Size, $\mathrm{mm}^{3}$ & $0.11 \times 0.04 \times 0.04$ & $0.30 \times 0.30 \times 0.20$ & $0.48 \times 0.41 \times 0.40$ & $0.38 \times 0.34 \times 0.30$ & $0.38 \times 0.34 \times 0.26$ & $0.46 \times 0.32 \times 0.30$ & $0.48 \times 0.48 \times 0.34$ \\
\hline MW, amu & 303.35 & 319.32 & 319.32 & 319.32 & 337.32 & 335.77 & 335.77 \\
\hline Crystal shape & flake & prism & prism & prism & prism & prism & prism \\
\hline Crystal system & triclinic & monoclinic & monoclinic & monoclinic & monoclinic & monoclinic & monoclinic \\
\hline Space group & $P \overline{1}(2)$ & $P 2_{1} / n(14)$ & $P 2_{1} / n(14)$ & $P 2_{1} / c(14)$ & $P 2_{1} / n(14)$ & $P 2_{1} / n(14)$ & $P 2_{1} / c(14)$ \\
\hline$a, \AA$ & $7.916(1)$ & $11.553(1)$ & $9.777(1)$ & $10.212(1)$ & $9.719(2)$ & $9.849(2)$ & $10.464(2)$ \\
\hline$b, \AA$ & 14.081(1) & $7.342(1)$ & $7.351(2)$ & $15.615(4)$ & $7.404(1)$ & $7.738(3)$ & $16.107(2)$ \\
\hline$c, \AA$ & $15.411(1)$ & $19.402(2)$ & 21.777(3) & $10.970(2)$ & $22.114(1)$ & $22.248(2)$ & $10.818(3)$ \\
\hline$\alpha, \operatorname{deg}$ & 73.961(1) & 90 & 90 & 90 & 90 & 90 & 90 \\
\hline$\beta$, deg & 82.917(1) & $106.125(3)$ & $93.75(1)$ & $115.633(1)$ & $93.61(2)$ & $93.50(1)$ & $115.70(1)$ \\
\hline$\gamma, \operatorname{deg}$ & $88.635(1)$ & 90 & 90 & 90 & 90 & 90 & 90 \\
\hline$V, \AA^{3}$ & $1638.3(1)$ & 1581.1(3) & $1561.8(4)$ & $1577.1(5)$ & $1588.2(4)$ & $1613.7(7)$ & $1642.9(6)$ \\
\hline$D_{\text {calcd }}, \mathrm{g} \mathrm{cm}^{-3}$ & 1.23 & 1.34 & 1.36 & 1.35 & 1.39 & 1.38 & 1.36 \\
\hline$Z$ & 4 & 4 & 4 & 4 & 4 & 4 & 4 \\
\hline$\mu, \mathrm{mm}^{-1}$ & 0.09 & 0.103 & 0.878 & 0.869 & 0.988 & 2.273 & 2.232 \\
\hline$T, \mathrm{~K}$ & 296 & 293 & 296 & 296 & 296 & 296 & 296 \\
\hline$F(000), \mathrm{e}$ & 648 & 672 & 672 & 672 & 704 & 704 & 704 \\
\hline $2 \theta$ range, deg & $3.49-28.78$ & $1.86-25.99$ & $4.07-54.95$ & $4.80-54.92$ & $4.01-54.97$ & $3.98-54.98$ & $4.69-54.94$ \\
\hline Range $h$ & $-10 / 10$ & $-14 / 11$ & $-10 / 10$ & $-10 / 0$ & $-10 / 10$ & $-10 / 10$ & $-11 / 10$ \\
\hline Range $k$ & $-16 / 19$ & $-9 / 9$ & $0 / 7$ & $-16 / 0$ & $-7 / 0$ & $0 / 7$ & $0 / 17$ \\
\hline Range $l$ & $-20 / 20$ & $-17 / 23$ & $0 / 23$ & $-10 / 11$ & $-23 / 0$ & $0 / 23$ & $0 / 11$ \\
\hline Scan mode & $\Phi-\omega$ & $\Phi-\omega$ & $\omega-2 \theta$ & $\omega-2 \theta$ & $\omega-2 \theta$ & $\omega-2 \theta$ & $\omega-2 \theta$ \\
\hline Refl. total & 14148 & 10043 & 2003 & 2084 & 2036 & 2071 & 2351 \\
\hline Refl. unique & 8189 & 3087 & 1944 & 1958 & 1978 & 2012 & 2054 \\
\hline$R_{\text {int }}$ & 0.003 & 0.004 & 0.003 & 0.003 & 0.002 & 0.001 & 0.001 \\
\hline $\begin{array}{l}\text { Refl. observ. } \\
{[I \geq 4 \sigma(I)]}\end{array}$ & 5077 & 2136 & 1912 & 1893 & 1955 & 1985 & 1991 \\
\hline Param. refined & 432 & 233 & 217 & 233 & 238 & 233 & 217 \\
\hline$R$ & 0.062 & 0.048 & 0.051 & 0.048 & 0.047 & 0.043 & 0.049 \\
\hline$R_{w}$ & 0.162 & 0.127 & 0.142 & 0.136 & 0.133 & 0.115 & 0.132 \\
\hline$\rho_{\max }$, e $\AA^{-3}$ & 0.26 & 0.25 & 0.31 & 0.31 & 0.30 & 0.31 & 0.32 \\
\hline CCDC No. & 626106 & 626107 & 626108 & 626109 & 626110 & 626111 & 626112 \\
\hline
\end{tabular}

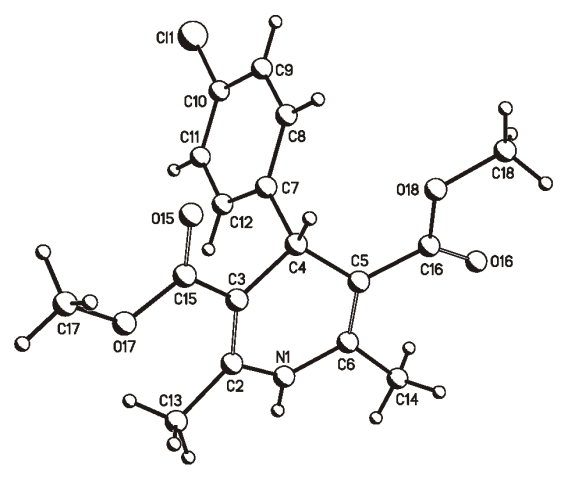

molecule 1

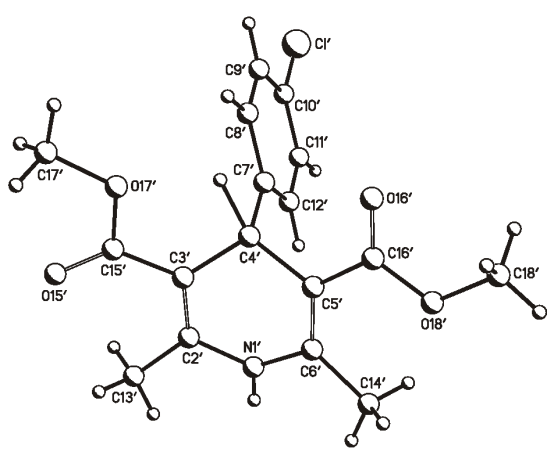

molecule 2
Fig. 4. Structures of the molecules in the crystals of orthorhombic $\mathbf{1 1}$. plane C2-C3-C5-C6 of the olefinic double bonds (Table 2). The pseudoaxial position of the 4-phenyl ring (Table 2, $\varphi_{1}$ ) [15], which is reported to be essential for pharmacological activity [16], is also accompanied by the rotation of the phenyl ring with respect to the bi- sectrize of the intraannular angle C3-C4-C5 (Table 2, $\left.\varphi_{2}\right)$. All unsymmetrically substituted dihydropyridines studied $(\mathbf{2}, 3,5,6,9,10,12$ and 13) exist as the synperiplanar rotamer $(s p)$, with the substituent on the phenyl ring positioned toward the hydrogen atom at 
Table 2. Geometric parameters of dihydropyridines $\mathbf{1}-\mathbf{1 4}$ from X-ray data.

\begin{tabular}{|c|c|c|c|c|c|c|c|c|c|c|}
\hline \multirow[t]{2}{*}{ Compound } & \multirow[t]{2}{*}{$\mathrm{X}$} & \multirow{2}{*}{$\begin{array}{l}\text { Space } \\
\text { group }\end{array}$} & \multicolumn{2}{|c|}{ Dist. atom-plane ${ }^{\mathrm{a}}, \AA$} & \multirow{2}{*}{$\begin{array}{c}\phi_{1}, \mathrm{deg} \\
\mathrm{C} 2-\mathrm{C} 3-\mathrm{C} 4-\mathrm{C} 7\end{array}$} & \multirow{2}{*}{$\begin{array}{c}\phi_{2}, \text { deg } \\
\text { H4-C4-C7-C8 }\end{array}$} & \multirow{2}{*}{ Rotamer $^{\mathrm{b}}$} & \multirow{2}{*}{$\begin{array}{c}\phi_{3}, \mathrm{deg} \\
\mathrm{C} 2-\mathrm{C} 3-\mathrm{C} 15-\mathrm{O} 15\end{array}$} & \multirow{2}{*}{$\begin{array}{c}\phi_{4}, \mathrm{deg} \\
\text { C6-C5-C16-O16 }\end{array}$} & \multirow[t]{2}{*}{ Ref. } \\
\hline & & & N1 & $\mathrm{C} 4$ & & & & & & \\
\hline 1 & $\mathrm{H}$ & $P \overline{1}$ & 0.147 & 0.356 & 94.65 & -15.81 & - & 179.20 & 4.05 & [7] \\
\hline \multirow[t]{2}{*}{$2^{c}$} & $o-\mathrm{Me}$ & $P \overline{1}$ & 0.098 & 0.221 & 105.16 & 1.26 & $s p$ & 178.06 & 14.37 & d \\
\hline & & & 0.132 & 0.278 & 101.22 & 1.01 & $s p$ & -11.76 & -179.82 & \\
\hline 3 & $m$-Me & $P 2_{1} / n$ & 0.147 & 0.315 & 99.48 & 3.00 & $s p$ & 169.49 & -11.05 & d \\
\hline 3 & $m$-Me & $P 2_{1} / c$ & 0.141 & 0.317 & 98.55 & 2.64 & $s p$ & 173.51 & 11.35 & [7] \\
\hline 4 & $p-\mathrm{Me}$ & $P 2_{1} / c$ & 0.135 & 0.295 & 100.11 & 19.70 & - & 158.88 & 17.66 & {$[7],{ }^{\mathrm{d}}$} \\
\hline 5 & $o-\mathrm{F}$ & $P 2_{1} / n$ & 0.150 & 0.338 & 96.26 & -6.58 & $s p$ & 166.03 & -0.05 & d \\
\hline 6 & $m-\mathrm{F}$ & $P 2_{1} / n$ & 0.163 & 0.343 & 96.76 & -37.17 & $s p$ & 168.01 & 1.06 & d \\
\hline 7 & $p-\mathrm{F}$ & $P 2_{1} / c$ & 0.150 & 0.319 & 99.15 & 19.55 & - & 152.11 & 13.69 & d \\
\hline 8 & $m, m-\mathrm{F}$ & $P 2_{1} / n$ & 0.144 & 0.324 & 98.18 & -37.24 & - & 170.79 & 7.32 & d \\
\hline \multirow[t]{2}{*}{$9^{c}$} & $o-\mathrm{Cl}$ & $P \overline{1}$ & 0.131 & 0.343 & 95.64 & 2.29 & $s p$ & 179.95 & 13.58 & [8] \\
\hline & & & 0.097 & 0.212 & 112.19 & 171.01 & $a p$ & 168.31 & -170.85 & \\
\hline 10 & $m-\mathrm{Cl}$ & $P 2_{1} / n$ & 0.165 & 0.351 & 95.74 & -37.22 & $s p$ & 170.33 & 7.01 & d \\
\hline 11 & $p-\mathrm{Cl}$ & $P 2_{1} / c$ & 0.132 & 0.303 & 98.40 & 27.53 & - & 176.40 & 9.22 & d \\
\hline \multirow[t]{2}{*}{$11^{\mathrm{c}}$} & $p-\mathrm{Cl}$ & $P 2_{1} 2_{1} 2_{1}$ & 0.149 & 0.320 & 98.42 & 27.54 & - & 176.38 & 9.26 & {$[9],{ }^{\mathrm{d}}$} \\
\hline & & & 0.169 & 0.341 & 95.41 & 12.50 & - & -2.89 & -178.16 & \\
\hline 12 & $o-\mathrm{NO}_{2}$ & $P 2_{1} / c$ & 0.107 & 0.230 & 100.79 & -13.90 & $s p$ & -169.98 & 11.13 & {$[10], \mathrm{d}, \mathrm{e}$} \\
\hline 13 & $m-\mathrm{NO}_{2}$ & $P 2_{1} / n$ & 0.150 & 0.317 & 99.63 & 5.45 & $s p$ & 179.96 & 7.94 & {$[7],{ }^{\mathrm{d}}$} \\
\hline 14 & $p-\mathrm{NO}_{2}$ & $P 2_{1} / c$ & 0.128 & 0.306 & 99.09 & -22.81 & - & 164.91 & 13.11 & {$[7],{ }^{d}$} \\
\hline
\end{tabular}

${ }^{a}$ Plane C2-C3-C5-C6; $\quad$ b syn-periplanar ( $s p$ ) and anti-periplanar (ap) orientation of the aryl group sustituent with respect to the H4-C4 bond; $\quad{ }^{\mathrm{c}}$ two molecules per asymmetric unit; ${ }^{\mathrm{d}}$ this work; $\quad{ }^{\mathrm{e}}$ triclinic polymorph $P \overline{1}$ is also known, see ref. [6].

\begin{tabular}{|c|c|c|c|c|c|c|c|}
\hline \multirow[b]{2}{*}{ Compound } & \multirow[b]{2}{*}{ X } & \multicolumn{2}{|c|}{ C-2/C-6 } & \multicolumn{2}{|l|}{$\mathrm{C}-3 / \mathrm{C}-5$} & \multicolumn{2}{|c|}{$\mathrm{C}-4$} \\
\hline & & Solid & $\mathrm{CDCl}_{3}$ & Solid & $\mathrm{CDCl}_{3}$ & Solid & $\mathrm{CDCl}_{3}$ \\
\hline 1 & $\mathrm{H}$ & $148.1,146.1$ & 144.4 & 102.8 & 103.7 & 38.6 & 39.3 \\
\hline 2 & $o$-Me & $148.2,143.8$ & 143.5 & $106.9,104.4$ & 105.0 & 36.3 & 35.6 \\
\hline $3^{\mathrm{a}}$ & $m$-Me & $150.3,146.2$ & 144.1 & 104.6 & 103.8 & 40.7 & 39.2 \\
\hline 4 & $p$-Me & $145.1 \mathrm{br}$ & 144.1 & 102.7 & 103.9 & 39.4 & 38.8 \\
\hline 5 & $o-\mathrm{F}$ & $149.0,146.0$ & 144.3 & $103.2,101.3$ & 102.7 & 31.8 & 34.4 \\
\hline 6 & $m-\mathrm{F}$ & $148.2,145.5$ & 144.4 & $102.8,99.9$ & 103.5 & 37.7 & 39.3 \\
\hline 7 & $p-\mathrm{F}$ & $146.9,144.5$ & 144.1 & $102.5,101.6$ & 103.9 & 39.8 & 38.8 \\
\hline 8 & $m, m-\mathrm{F}$ & $147.5,146.1$ & 144.7 & 102.0 & 103.0 & 37.5 & 39.4 \\
\hline 9 & $o-\mathrm{Cl}$ & $146.4 \mathrm{br}$ & 144.0 & $103.0,102.5,100.5,96.7$ & 103.9 & 35.0 & 37.2 \\
\hline 10 & $m-\mathrm{Cl}$ & $149.1 \mathrm{br}$ & 144.4 & $102.5,100.6$ & 103.4 & 37.8 & 39.3 \\
\hline $11^{\mathrm{b}}$ & $p-\mathrm{Cl}$ & $147.7,145.1$ & 144.2 & 102.0 & 103.6 & 39.4 & 39.0 \\
\hline $11^{\mathrm{c}}$ & $p-\mathrm{Cl}$ & $149.4,146.8$ & 144.2 & $102.6^{\mathrm{d}}, 101.0$ & 103.6 & 39.6 & 39.0 \\
\hline $12^{\mathrm{b}}$ & $o-\mathrm{NO}_{2}$ & $148.1,143.8$ & 145.1 & $102.8,101.2$ & 103.4 & 35.1 & 34.5 \\
\hline 13 & $m-\mathrm{NO}_{2}$ & $151.6,147.2$ & 145.0 & 103.2 & 103.1 & 41.1 & 39.7 \\
\hline 14 & $p-\mathrm{NO}_{2}$ & 146.4 & 144.8 & 101.4 & 102.9 & 40.1 & 39.8 \\
\hline
\end{tabular}

Table $3 .{ }^{13} \mathrm{C}$ NMR chemical shifts (solid and solution state) of the dihydropyridine moiety for $1-14$.

a Space group $P 2{ }_{1} / n$

b space group $P 2_{1} / c$;

c space group $P 2{ }_{1} 22_{1}$;

d for three carbon signals.
C4, except for 9 in which one of two molecules in the asymmetric unit exists as the anti-periplanar rotamer (ap) [8] (Fig. 3). Pharmacological studies suggest that such syn-periplanar orientations are the receptor-bonded conformations [17]. Examination of Table $2\left(\varphi_{3}, \varphi_{4}\right)$ also revealed that both carboxyl groups remain nearly coplanar with the plane of the dihydropyridine ring (C2-C3-C5-C6) and show a preference for the $s$ - cis/strans conformation with respect to the same plane independent of the $o$-phenyl substitution, except for 9 in which one of two molecules in the asymmetric unit exists as the $s$-trans/s-trans conformer (Fig. 3). The $s$ cis arrangement of at least one of the carbonyl groups seems to be enough for a satisfactory calcium antagonist effect and for hydrogen bonding to the receptor $[18,19]$.

\section{${ }^{13}$ C CP-MAS NMR spectra}

The peak assignments for the ${ }^{13} \mathrm{C}$ solid state and solution NMR spectra of DHPs $\mathbf{1 - 1 4}$ are shown in Tables $3-5$. For the solid state assignments, comparisons with the solution state data were used [20] and dipolar dephasing experiments identified peaks of quaternary and methyl carbon atoms. It is clear that although the phenyl ring twisting in DHPs 2, 3, 5, 9 and 13 is 


\begin{tabular}{|c|c|c|c|c|c|c|c|}
\hline \multirow[b]{2}{*}{ Compound } & \multirow[b]{2}{*}{$\mathrm{X}$} & \multicolumn{2}{|c|}{$\mathrm{C}=\mathrm{O}$} & \multicolumn{2}{|l|}{$\mathrm{OCH}_{3}$} & \multicolumn{2}{|l|}{$\mathrm{CH}_{3}$} \\
\hline & & Solid & $\mathrm{CDCl}_{3}$ & Solid & $\mathrm{CDCl}_{3}$ & Solid & $\mathrm{CDCl}_{3}$ \\
\hline 1 & $\mathrm{H}$ & $169.4,167.4$ & 168.1 & $53.0,52.2$ & 51.0 & $19.5,18.8$ & 19.4 \\
\hline 2 & $o-\mathrm{Me}$ & $169.2,167.7$ & 168.0 & 50.3, br & 50.8 & $19.1 \mathrm{br}$ & 19.7 \\
\hline $3^{\mathrm{a}}$ & $m$-Me & $170.7,168.1$ & 168.0 & $53.4,51.2$ & 51.0 & 21.3 & 19.6 \\
\hline 4 & $p$-Me & $171.4,167.7$ & 168.0 & $52.3,48.7$ & 51.0 & 17.5 & 19.6 \\
\hline 5 & $o-\mathrm{F}$ & $169.3,167.7$ & 167.8 & 52.1 & 50.9 & $19.0,18.2$ & 19.5 \\
\hline 6 & $m-\mathrm{F}$ & $170.5,167.3$ & 167.3 & $52.6,52.0$ & 51.0 & $19.0,18.5$ & 19.6 \\
\hline 7 & $p-\mathrm{F}$ & $172.9,167.8$ & 167.8 & $53.6,49.3$ & 51.0 & $19.0,17.4$ & 19.6 \\
\hline 8 & $m, m-\mathrm{F}$ & $170.0,167.8$ & 167.5 & 52.1 & 51.1 & 18.9 & 19.6 \\
\hline 9 & $o-\mathrm{Cl}$ & $169.9,166.9$ & 167.9 & $52.6^{\mathrm{d}}, 51.3,50.0$ & 50.8 & $18.4^{\mathrm{e}}, 14.6$ & 19.4 \\
\hline 10 & $m-\mathrm{Cl}$ & $170.7,167.8$ & 167.7 & $53.5,52.7$ & 51.1 & $20.7,19.1$ & 19.6 \\
\hline $11^{\mathrm{b}}$ & $p-\mathrm{Cl}$ & $171.7,167.3$ & 167.7 & $53.2,48.8$ & 51.0 & 17.9 & 19.6 \\
\hline $11^{\mathrm{c}}$ & $p-\mathrm{Cl}$ & $169.9,167.5$ & 167.7 & $53.8,51.9,51.1,50.2$ & 51.0 & $20.8^{\mathrm{d}}, 18.4,17.1$ & 19.6 \\
\hline $12^{\mathrm{b}}$ & $o-\mathrm{NO}_{2}$ & $169.6,167.7$ & 167.6 & $50.8,48.0$ & 50.9 & 18.9 & 19.3 \\
\hline 13 & $m-\mathrm{NO}_{2}$ & $170.9,167.2$ & 167.5 & 53.2 & 51.2 & 21.4 & 19.6 \\
\hline 14 & $p-\mathrm{NO}_{2}$ & $172.3,167.5$ & 167.3 & $52.0,49.9$ & 51.1 & 18.1 & 19.6 \\
\hline
\end{tabular}

Table $4 .{ }^{13} \mathrm{C}$ NMR chemical shifts (solid and solution state) of the dihydropyridine substituents for $1-14$.

a Space group $P 21 / n$;

b space group $P 2_{1} / c$;

${ }^{c}$ space group $P 2{ }_{1} 22_{1}$;

d for two carbon signals;

$\mathrm{e}$ for three carbon signals.

Table $5 .{ }^{13} \mathrm{C}$ NMR chemical shifts (solid and solution state) of the benzene rings in $\mathbf{1 - 1 4}$.

\begin{tabular}{|c|c|c|c|c|c|c|c|c|c|c|c|c|c|}
\hline \multirow[b]{2}{*}{ Compound } & \multirow[b]{2}{*}{$\mathrm{X}$} & \multicolumn{2}{|c|}{$\mathrm{C}-7$} & \multicolumn{2}{|r|}{ C-8 } & \multicolumn{2}{|c|}{ C-9 } & \multicolumn{2}{|c|}{ C-10 } & \multicolumn{2}{|c|}{$\mathrm{C}-11$} & \multicolumn{2}{|c|}{ C-12 } \\
\hline & & Solid & $\mathrm{CDCl}_{3}$ & Solid & $\mathrm{CDCl}_{3}$ & Solid & $\mathrm{CDCl}_{3}$ & Solid & $\mathrm{CDCl}_{3}$ & Solid & $\mathrm{CDCl}_{3}$ & Solid & $\mathrm{CDCl}_{3}$ \\
\hline 1 & $\mathrm{H}$ & 146.1 & 147.4 & 126.4 & 127.6 & 128.5 & 128.0 & 126.4 & 128.5 & 126.4 & 128.0 & 126.4 & 127.6 \\
\hline 2 & $o-\mathrm{Me}^{\mathrm{e}}$ & 143.8 & 147.5 & 136.0 & 135.1 & 129.9 & 129.7 & 128.0 & 126.0 & 128.0 & 126.0 & 129.9 & 129.2 \\
\hline $3^{\text {a }}$ & $m-\mathrm{Me}^{\mathrm{e}}$ & 146.2 & 147.2 & 129.2 & 128.2 & 137.0 & 137.4 & 126.8 & 127.0 & 129.2 & 127.8 & 126.8 & 124.6 \\
\hline 4 & $p-\mathrm{Me}^{\mathrm{e}}$ & $145.1 \mathrm{br}$ & 144.5 & 128.0 & 127.4 & 131.0 & 128.7 & 134.2 & 135.6 & 131.0 & 128.7 & 128.0 & 127.4 \\
\hline 5 & $o-\mathrm{F}^{\mathrm{f}}$ & 135.6 & 134.4 & 155.7 & 159.9 & 114.1 & 115.1 & 129.1 & 127.7 & 123.4 & 123.7 & 129.1 & 130.7 \\
\hline 6 & $m-\mathrm{F}^{\mathrm{f}}$ & 148.2 & 149.8 & 113.7 & 114.4 & 161.6 & 162.8 & 113.7 & 113.0 & 129.4 & 129.2 & 122.4 & 123.2 \\
\hline 7 & $p-\mathrm{F}^{\mathrm{f}}$ & 144.5 & 143.3 & 131.3 & 129.0 & 114.4 & 114.6 & 160.5 & 161.3 & 114.4 & 114.6 & 131.3 & 129.0 \\
\hline 8 & $m, m-\mathrm{F}^{\mathrm{f}}$ & $150.9 \mathrm{br}$ & 151.1 & 109.8 & 110.3 & 161.8 & 162.8 & 100.3 & 101.6 & 161.8 & 162.8 & 109.8 & 110.3 \\
\hline $9^{\mathrm{b}}$ & $o-\mathrm{Cl}$ & $146.4 \mathrm{br}$ & 145.8 & 135.0 & 132.3 & 128.6 & 129.2 & 128.6 & 126.8 & 128.6 & 127.2 & 128.6 & 131.1 \\
\hline $10^{\mathrm{b}}$ & $m-\mathrm{Cl}$ & $149.1 \mathrm{br}$ & 149.3 & 127.3 & 127.7 & 137.6 & 133.8 & 127.3 & 126.3 & 127.3 & 129.1 & 127.3 & 125.9 \\
\hline $11^{\mathrm{b}, \mathrm{c}}$ & $p-\mathrm{Cl}$ & 145.1 & 145.9 & 130.0 & 129.0 & 130.0 & 128.1 & 130.8 & 131.8 & 130.0 & 128.1 & 130.0 & 129.0 \\
\hline $11^{\mathrm{b}, \mathrm{d}}$ & $p-\mathrm{Cl}$ & 146.8 & 145.9 & 129.1 & 128.1 & 129.1 & 129.0 & 129.1 & 131.8 & 129.1 & 129.0 & 129.1 & 128.1 \\
\hline $12^{\mathrm{c}}$ & $o-\mathrm{NO}_{2}$ & 143.8 & 142.1 & 148.1 & 147.8 & 123.7 & 123.8 & 126.4 & 127.0 & 135.9 & 132.7 & 135.9 & 131.0 \\
\hline 13 & $m-\mathrm{NO}_{2}$ & 147.2 & 149.6 & 122.9 & 122.7 & 147.2 & 148.4 & 122.9 & 121.4 & 130.5 & 128.7 & 136.8 & 134.2 \\
\hline 14 & $p-\mathrm{NO}_{2}$ & 155.9 & 154.6 & 130.0 & 128.5 & 124.4 & 123.3 & 146.4 & 146.3 & 124.4 & 123.3 & 130.0 & 128.5 \\
\hline
\end{tabular}

${ }^{a}$ Space group $P 2{ }_{1} / n ; \quad$ b large line widths and severe overlapping; $\quad{ }^{\mathrm{c}}$ space group $P 22_{1} / c ; \quad{ }^{\mathrm{d}}$ space group $P 2{ }_{1} 2{ }_{1} 2_{1} ; \quad{ }^{\mathrm{e}} \delta\left({ }^{13} \mathrm{C}\right), \mathrm{ppm}$ (solid and solution state); 2: $\mathrm{H}_{3} \mathrm{C}-\mathrm{Ar} 21.3,19.1 ; 3: \mathrm{H}_{3} \mathrm{C}-\mathrm{Ar} 21.3,21.7 ; 4: \mathrm{H}_{3} \mathrm{C}-\mathrm{Ar} 21.7,21.1 ; \quad{ }^{\mathrm{f}}{ }^{n} J_{(\mathrm{C}, \mathrm{F})}, \mathrm{Hz} ; \mathbf{5}:{ }^{1} J_{(\mathrm{C} 8, \mathrm{~F})}=247.5,{ }^{2} J_{(\mathrm{C} 7, \mathrm{~F})}=$ $13.8,{ }^{2} J_{(\mathrm{C} 9, \mathrm{~F})}=23.1,{ }^{3} J_{(\mathrm{C} 10, \mathrm{~F})}=8.3,{ }^{3} J_{(\mathrm{C} 12, \mathrm{~F})}=4.6,{ }^{4} J_{(\mathrm{C} 11, \mathrm{~F})}=3.4 ; 6:{ }^{1} J_{(\mathrm{C} 9, \mathrm{~F})}=243.3,{ }^{2} J_{(\mathrm{C} 8, \mathrm{~F})}={ }^{2} J_{(\mathrm{C} 10, \mathrm{~F})}=21.1,{ }^{3} J_{(\mathrm{C} 7, \mathrm{~F})}=6.4{ }^{3} J_{(\mathrm{C} 11, \mathrm{~F})}=$ 8.0; 7: ${ }^{1} J_{(\mathrm{C} 10, \mathrm{~F})}=244.6,{ }^{2} J_{(\mathrm{C} 9, \mathrm{~F})}={ }^{2} J_{(\mathrm{C} 11, \mathrm{~F})}=21.0,{ }^{3} J_{(\mathrm{C} 8, \mathrm{~F})}={ }^{3} J_{(\mathrm{C} 12, \mathrm{~F})}=7.9 ; 8:{ }^{1} J_{(\mathrm{C} 9, \mathrm{~F})}={ }^{1} J_{(\mathrm{C} 11, \mathrm{~F})}=246.9,{ }^{2} J_{(\mathrm{C} 8, \mathrm{~F})}={ }^{2} J_{(\mathrm{C} 10, \mathrm{~F})}={ }^{2} J_{(\mathrm{C} 12, \mathrm{~F})}=$ $25.9,{ }^{3} J_{(\mathrm{C} 9, \mathrm{~F})}={ }^{3} J_{(\mathrm{C} 11, \mathrm{~F})}=12.6$.

smaller than $7^{\circ}$ (Table 2, $\varphi_{2}$ ), the expected magnetic non-equivalence of the carbon atoms at each side of the plane containing the $\mathrm{N}-1, \mathrm{C}-4, \mathrm{C}-7$ atoms is due to the molecular asymmetry of the s-cis/s-trans arrangement of the carbonyl groups. Thus, the crystallographic asymmetric unit observed in the crystal structures of DHPs $1-14$ is evidenced by the splitting of the olefinic C-2/C-6 signals into a doublet on going from solution (in which the asymmetry is lost) to the solid state spectra. The splitting ranges for the C-2/C-6 carbons are about $2.0-4.5 \mathrm{ppm}$. These carbons, in the direct vicinity of a ${ }^{14} \mathrm{~N}$ nucleus, are affected by the dipolar coupling to the $I=1{ }^{14} \mathrm{~N}$ nucleus, leading to signal broadening $[21,22]$. In addition, a systematic signal splitting in the range of about 1.5-5.0 ppm was also observed for the carbonyl carbons at the dihydropyridine ring (Table 4).

The extent to which the carbonyl carbon peak is split strongly depends upon the substitution pattern of the phenyl ring. The largest peak splitting was found for the carbonyl carbons of para-substituted DHPs and decreased in the order para $>$ meta $>$ ortho. In contrast, the magnitude of the peak splitting of C-2/C-6 carbons follows a reverse trend, with ortho-substituted DHPs showing a larger peak splitting (see Tables 3 and 4). These observations are obviously connected to the through-space contribution in the propagation of the substituent effects, the way in which the aro- 
matic ring is positioned with respect to the hetero ring in the solid and the deviation of the dihydropyridine ring from planarity.

A prominent feature of DHP 9 and the orthorhombic polymorph of $\mathbf{1 1}$ is that the two molecules per asymmetric unit differ in their conformational properties, in contrast to DHP 2 for which the two molecules in the asymmetric unit are conformationally similar (see Figs. 2-4). Molecule 1 in the crystalline structure of DHP 9 possesses a $s$-cis/s-trans arrangement of the carbonyl groups with the phenyl ring as a syn-periplanar rotamer, twisted by $2.29^{\circ}$. In contrast, molecule 2 of 9 shows a $s$-trans/s-trans arrangement of the carboxyl groups with the phenyl ring as an anti-periplanar rotamer, twisted by $171.01^{\circ}$ (Table 2). Although in the orthorhombic structure of $\mathbf{1 1}$ both molecules have the carboxyl groups s-cis/s-trans oriented, the most obvious difference is noted for the twisting of the phenyl ring which varies from $27.54^{\circ}$ for molecule 1 to $12.50^{\circ}$ for molecule 2 (Table 2). The structures of molecules 2 are similar and are characterized by having their carbonyl groups s-cis/s-trans oriented and the phenyl rings as syn-periplanar rotamers. The phenyl ring twisting in both molecules differs in detail and is $1.26^{\circ}$ for molecule 1 and $1.01^{\circ}$ for molecule 2 (Table 2).

The expected different environments for each of the two molecules present in the corresponding asymmetric unit of the unit cells of DHPs 9 (Fig. 3) and orthorhombic 11 (Fig. 4) is consistent with the splitting pattern observed for the peaks owing to the $\mathrm{OCH}_{3}$ and $\mathrm{CH}_{3}$ carbons at $\mathrm{C}-2 / \mathrm{C}-6$ in the ${ }^{13} \mathrm{C}$ solid state spectra, which appear either as narrow doublets (3:1 ratio), triplets $(2: 1: 1$ ratio) or quadruplets $(1: 1: 1: 1$ ratio) (Table 4). In contrast, in the case of DHP 2 (Fig. 2) only a broad single signal is observed for the $\mathrm{OCH}_{3}$ and $\mathrm{CH}_{3}$ carbons at $\mathrm{C}-2 / \mathrm{C}-6$.

An accurate solid state NMR assignment of the corresponding benzene ring signals in chlorinated DHPs 9-11 is hardly possible due to strong line broadening and severe signal overlapping in the region $\delta_{\mathrm{C}}=$ $127-130 \mathrm{ppm}$. Extra splitting of spectral lines for carbon atoms bonded to chlorine [13] can be explained by the presence of second-order effects arising from the quadrupole moments of ${ }^{35} \mathrm{Cl}$ and ${ }^{37} \mathrm{Cl}$.

\section{Conclusion}

The CP-MAS NMR spectra of solid DHPs are consistent with the crystallographic asymmetric units con- taining one or two molecules as determined by X-ray diffraction. In the case of $\mathbf{2 , 9}$ and orthorhombic 11, which contain two molecules per asymmetric unit of the crystal cell, the multiplicity and ratio observed for the $\mathrm{OCH}_{3}$ and $\mathrm{CH}_{3}$ carbons signals at $\mathrm{C}-2 / \mathrm{C}-6$ are in accord with the observed conformational differences between the two molecules in the unit cell. The solid state NMR spectra reveal that the extent to which the carbonyl peaks and those of C-2/C-6 split strongly depends upon the substitution pattern of the phenyl ring.

\section{Experimental Section}

The studied DHPs $\mathbf{1} \mathbf{- 1 4}$ were obtained by standard procedures through condensation of a $\beta$-enaminoester with an appropriate aldehyde, and a $\beta$-ketoester as described previously [23].

\section{$X$-Ray diffraction}

Single crystals of $\mathbf{2}, \mathbf{5}-\mathbf{8}, \mathbf{1 0}$ and $\mathbf{1 1}$ were grown by slow crystallization from $\mathrm{MeOH}$. The X-ray data of $\mathbf{2}$ and $\mathbf{5}$ were collected on a Bruker Smart 6000 CCD diffractometer using $\operatorname{Mo} K_{\alpha}$ radiation $(\lambda=0.71073 \AA)$. A total of 1321 frames were collected with a scan width of $0.3^{\circ}$ and an exposure time of $10 \mathrm{~s} /$ frame. The frames were processed with the SAINT software package, provided by the diffractometer manufacturer. The X-ray data of 6-8, 10 and 11 were measured on a Bruker-Nonius CAD4 diffractometer with $\mathrm{Cu} K_{\alpha}$ radiation $(\lambda=1.54184 \AA)$. The data were collected in the $\omega-2 \theta$ scan mode. Unit cell refinements were carried out using the CAD4 Express v2.0 software. All structures were solved by Direct Methods using the SHELXS-97 program included in the WINGX v1.64.05 crystallographic software package. For the structure refinement, the nonhydrogen atoms were treated anisotropically, and the hydrogen atoms included in the structure factor calculation, were refined isotropically. Crystal data, collection and refinement parameters are given in Table 1.

Crystallographic data (excluding structure factors) have been deposited at the Cambridge Crystallographic Data Centre. The respective CCDC numbers are indicated in Table 1. These data can be obtained free of charge from The Cambridge Crystallographic Data Centre via http:// www.ccdc.cam.ac.uk/data_request/cif.

\section{Solution and solid state ${ }^{13}$ C NMR}

Solution ${ }^{13} \mathrm{C}$ NMR spectra were recorded at r.t. on Varian Gemini 200, Varian Mercury 300 and Varian Unity Plus 300 instruments, using $\mathrm{CDCl}_{3}$ as a solvent. Spectra were referenced relative to internal TMS. For the ${ }^{13} \mathrm{C}-{ }^{1} \mathrm{H}$ HETCOR experiments, a standard pulse sequence was used. The spectra 
were acquired with 1024 data points and 256 increments with 64 transients per increment. The relaxation delay was $1 \mathrm{~s}$ and ${ }^{1} \mathrm{~J}(\mathrm{C}, \mathrm{H})$ was assumed to be $140 \mathrm{~Hz}$. Solid state ${ }^{13} \mathrm{C}$ NMR spectra were recorded under proton decoupling on Varian Unity Plus 300 and Bruker Avance 400 NMR spectrometers. Approximately $150 \mathrm{mg}$ were packed into $7 \mathrm{~mm}$ diameter zirconium rotors, with Kel-F packs. $5 \mathrm{~mm}$ diameter rotors were used in the Bruker spectrometer. The spectra were obtained under Hartmann-Hahn matching conditions and a spinning rate of $7.5 \mathrm{kHz}$ was used. A contact time of $2.5 \mathrm{~ms}$ and a repetition time of $6 \mathrm{~s}$ were used. The measurements were made using spin-lock power in radiofrequency units of $60 \mathrm{kHz}$ and typically 2,000 transients were recorded. In some spectra, elimination of spinning side bands was accomplished by the TOSS sequence [24]. Spectra to identify non-protonated carbons were recorded using interrupted decoupling for $100 \mu \mathrm{s}$ after cross-polarization [25]. Chemical shifts were referenced to the upfield peak of adamantane at $29.5 \mathrm{ppm}$ with respect to TMS, as determined on a separate sample.
[1] B.G. Katzung in Basic and Clinical Pharmacology (Ed.: B. G. Katzung), Appleton \& Lange, Stamford 1998, pp. $179-196$.

[2] D. J. Triggle, Eur. J. Biochem. 1999, 375, 311-325.

[3] W. A. Catterall, J. Striessnig, T. P. Snutch, E. PerezReyes, Pharmacol. Rev. 2003, 55, 579-581.

[4] P. Hess, J. B. Lansman, R. W. Tsien, Nature 1984, 311, $538-544$.

[5] J. Striessnig, Cell. Physiol. Biochem. 1999, 9, $242-$ 269.

[6] M. R. Caira, Y. Robbertse, J. J. Bergh, M. Song, M. M. De Villiers, J. Pharm. Sci. 2003, 92, 2519-2533.

[7] R. Fossheim, K. Svarteng, A. Mostad, C. Romming, E. Shefter, D. J. Triggle, J. Med. Chem. 1982, 25, $126-$ 131.

[8] G. Rovnyak, N. Andersen, J. Gougoutas, A. Hedberg, S. D. Kimball, M. Malley, S. Moreland, M. Porubcan, A. Pudzianowski, J. Med. Chem. 1988, 31, 936-944.

[9] N. K. Lokanath, M. A. Sridhar, J. Shashidhara Prasad, M. Joshi, D. A. Thaker, A. Shah, Z. Kristallog.-New Cryst. Struct. 1997, 212, 13-14.

[10] A. M. Triggle, E. Shefter, D. J. Triggle, J. Med. Chem. 1980, 23, $1442-1445$.

[11] G. R. Hays, R. Huis, B. Coleman, D. Clague, J. W. Verhoeven, F. Rob, J. Am. Chem. Soc. 1981, 103, 51405146.

[12] A. Hilgeroth, G. Hempel, U. Baumeister, D. Reichert, Solid State NMR 1999, 13, $231-243$.
[13] D. C. Apperley, A. H. Forster, R. Fournier, R. K. Harris, P. Hodgkinson, R. W. Lancaster, T. Rades, Magn. Reson. Chem. 2005, 43, 881-892.

[14] H. J. Hofmann, R. Cimiraglia, Theochem. 1990, 64, 1 11.

[15] R. Davis, J. R. Kern, L. J. Kurz, J.R. Pfister, J. Am. Chem. Soc. 1988, 110, 7873-7874.

[16] R. Fossheim, A. Joslyn, A. J. Solo, E. Luchowski, A. Rutledge, D. J. Triggle, J. Med. Chem. 1988, 31, $300-305$.

[17] G. Rovnyak, N. Andersen, J. Gougoutas, A. Hedberg, S.D. Kimball, M. Malley, S. Moreland, M. Porubcan, A. Pudzianowski, J. Med. Chem. 1991, 34, 2521 2524.

[18] R. Fossheim, J. Med. Chem. 1986, 27, 544-548.

[19] M. Mahmoudian, W. G. Richards, J. Pharm. Pharmacol. 1986, 38, $272-276$.

[20] M. S. Morales-Ríos, A. De la Cerda Medina, V. PérezAlvarez, P. Joseph-Nathan, Magn. Reson. Chem. 2000, $38,680-683$.

[21] D. P. Weliky, R. Tycko, J. Am. Chem. Soc. 1996, 118, $8487-8488$.

[22] K. Saalwächter, K. Schmidt-Rohr, J. Magn. Reson. 2000, 145, $161-172$.

[23] A. Hantzsch, Justus Liebigs Ann. Chem. 1882, 215, 1 82.

[24] W. T. Dixon, J. Chem. Phys. 1982, 77, 1800-1809.

[25] S. J. Opella, M. H. Frey, J. Am. Chem. Soc. 1979, 101, $5854-5856$. 